\title{
Need of Assessment of Folic Acid and Vitamin B12 in Pregnancy
}

\author{
Srilatha Bashetti ${ }^{1}$, Bhongir Aparna Varma ${ }^{2}$, Kumar Sai Sailesh ${ }^{3}$ and Rajagopalan Vijayaraghavan ${ }^{4}$ \\ ${ }^{1}$ Department of Biochemistry, Apollo Institute of Medical sciences \& Research, India \\ ${ }^{2}$ Departmentof Biochemistry, Mediciti Institute of Medical Sciences, India \\ ${ }^{3}$ Department of Physiology, Little Flower Institute of Medical Sciences and Research, India \\ ${ }^{4}$ Department of Research, Saveetha University, India
}

Submission: March 22, 2017; Published: March 28, 2017

*Corresponding author: Srilatha Bashetti, Department of Biochemistry, Apollo Institute of Medical sciences \& Research (AIMSR), Hyderabad,

Telangana, India, Email: srilathabasetty@gmail.com

\section{Letter to Editor}

Pregnancy symptoms and complications can range from mild and annoying discomforts to severe, sometimes life-threatening illnesses. Problems during pregnancy may include physical and mental conditions that affect the health of the mother or the baby. One such complication is thyroid dysfunction noticed in pregnancy. Hypothyroidism is relatively common in pregnancy and is very important to treat. Estimated prevalence of overt hypothyroidism is $0.3-0.5 \%$, subclinical hypothyroidism is $2-3 \%$ and $8-14 \%$ of women in child bearing age are positive to thyroid antibodies. Most common causes include chronic autoimmune thyroiditis and iodine deficiency. It may be also due to modifications in autoimmune regulation and placental deiodinase role. Folic acid an essential micronutrient in all stages of life, it plays an important role in the synthesis of DNA, methylation reactions, development and maintenance of healthy nervous system.

Vitamin B12 during pregnancy is required for fetal development and infant growth-states the dependency of the fetus on maternal vitamin B12 and has an impact on cognitive ability of children later in life. Thus, there is increasing demands for excess supplementation of vitamin B12 [1]. 12\% of the hypothyroid patients express one of the clinical signs of Vitamin B12 deficiency (Pernicious anemia). High prevalence suggests that the hypothyroid patients should be screened for vitamin B12 levels irrespective of thyroid antibody status [2]. Supplementation of folic acid is common in pregnancy. On the other hand deficiency of vitamin B12 is commonly noticed in pregnancy. May be due to wide spread vegetarianism. Few studies stated that low vitamin B12 is associated with increased risk of fetal NTDs and IUGR [3]. On the other hand excess of folic acid may have harmful effect on the nervous system in the presence of Vitamin B12 deficiency.

High plasma folate and low vitamin B12 showed the relation to cognitive impairment [4]. Availability of methyl group is very important for many cellular functions of neuron to occur, including gene expression control and DNA methylation, nucleic acid synthesis and repair and protein metabolism. Important vitamins for methyl group transfer and availability are vitamin B6, Folic acid (B9), Vitamin B12 and choline. As a precaution to prevent NTD's FA supplementation is recommended during pregnancy, this is a simple intervention to greatly reduce the incidence of NTD's in offspring. Supplementation of folate in adults was suggested to prevent neurodegeneration and to improve of cognitive abilities and reduce depressive symptoms. But, few studies had stated that excess supplementation of folic acid may lead to certain complications like it may promote or increases the prognosis of carcinogenesis [5] or may have suppressive effect on thyroid hormones (T3 and T4 but not TSH) [6] was the first to learn the prolonged effects of folate supplementation in an animal study.

The detrimental effect of high folate on endocrine and behavioral parameters suggests "anything in excess is very bad." It is essential to focus on the patterns of FT3, FT4 and TSH with excess or normal folic acid and with or without vitamin B12 deficiency in pregnant women with subclinical hypothyroidism and overt hypothyroidism. This is to notice whether in humans the increased folate supplementation during pregnancy i.e. high intake of folic acid have any impact on maternal plasma thyroid hormonal levels. 


\section{References}

1. Steen MT, Boddie AM, Fisher AJ, Macmahon W, Saxe D, et al. (1998) Neural-tube defects are associated with low concentrations of cobalamin (vitamin B12) in amniotic fluid. Prenat Diagn 18(6): 545555 .

2. Jabbar A, Yawar A, Waseem S, Islam N, Ul Haque N, et al. (2008) Vitamin B12 deficiency common in primary hypothyroidism. J Pak Med Assoc 58(5): 258-261

3. Muthayya S, Kurpad AV, Duggan C, Bosch RJ, Dwarkanath P, et al. (2006) Low maternal vitamin B12 status is associated with intrauterine growth retardation in urban South Indians. Eur J Clin Nutr 60(6): 791 801.
4. Selhub J, Paul L (2011) Folic acid fortification: why not vitamin B12 also? Biofactors 37(4): 269-271.

5. Collin SM, Metcalfe C, Refsum H, Lewis SJ, Zuccolo L, et al. (2010) Circulating folate, vitamin B12, homocysteine, vitamin B12 transport proteins, and risk of prostate cancer: a case-control study, systematic review, and meta-analysis. Cancer Epidemiol Biomarkers Prev 19(6): $1632-1642$

6. Sittig LJ, Herzing LB, Shukla PK, Redei EE (2011a) Parent-of-origin allelic contributions to deiodinase-3 expression elicit localized hyperthyroid milieu in the hippocampus. Mol Psychiatry 16(8): 786787.

\section{Your next submission with Juniper Publishers will reach you the below assets}

- Quality Editorial service

- Swift Peer Review

- Reprints availability

- E-prints Service

- Manuscript Podcast for convenient understanding

- Global attainment for your research

- Manuscript accessibility in different formats ( Pdf, E-pub, Full Text, Audio)

- Unceasing customer service

Track the below URL for one-step submission https://juniperpublishers.com/online-submission.php 